\title{
INFORMACE O VYDÁNÍ REVIDOVANÉHO PŘEKLADU MILLSOVY SOCIOLOGICKÉ IMAGINACE V SOCIOLOGICKÉM NAKLADATELSTVÍ (SLON)
}

\author{
ALENA MILTOVÁ \\ Sociologické nakladatelství (SLON) \\ E-mail: alena.miltova2020@gmail.com
}

I v nakladatelstvích mají knihy své př́iběhy. V následujícím textu stručně představím př́běh vydání Sociologické imaginace (2002) v Sociologickém nakladatelství (SLON). Millsova Sociologická imaginace vyšla česky poprvé v roce 1968 v nakladatelství Mladá fronta v překladu Václava Duška a s doslovem Lubomíra Sochora (Mills, 1968). Z tiráže tehdejšího vydání se dozvídáme, že kniha vyšla v nákladu 6500 výtisků. V Sociologickém nakladatelství (SLON) jsme o novém vydání této slavné Millsovy knihy uvažovali od poloviny 90. let, kdy Miloslav Petrusek vytvořil koncepci ediční řady MOST (Moderní sociologická teorie). Kniha pak vyšla jako druhý svazek této řady. Předcházela tomu ale spousta práce.

Co musí nakladatelství udělat, aby mohlo vydat překlad nějaké knihy? Ze všeho nejdřive musí koupit práva $\mathrm{k}$ překladu od nakladatelství, které má práva k originálu knihy to už může být po letech, která uběhnou od původního vydání, úplně jiné nakladatelství, nebot’s autorskými právy se čile obchoduje. $V$ prípadě Millsovy knihy jím zůstalo nakladatelství Oxford University Press, které jsme v listopadu 1999 oslovili dopisem, následná korespondence pokračovala za pomoci faxu. (Dnes se vše samozřejmě vyřizuje e-mailem.) Hned na počátku jsme obdrželi důležitou informaci, že práva k českému vydání jsou volná. Poté začalo vyjednávání o částce, kterou za tato práva zaplatíme - odvozuje se od předpokládané výše nákladu a prodejní ceny v českých korunách. Předpokládali jsme náklad 1300 výtisků a prodejní cenu 187 Kč (což bylo naivní: kniha nakonec stála 288 Kč). Při podpisu smlouvy jsme zaplatili zálohu 800 dolarů (to bylo tehdy dost peněz) a získali jsme licenci na šest let.

Tehdy jsme se také dozvěděli, že Oxford UP připravuje speciální vydání Sociologické imaginace s novým doslovem Todda Gitlina, a to ke 40. výročí prvního vydání. Do konce roku 1999 ale vydat knihu nestihli, vyšla až v roce 2000 (Mills, 2000). Okamžitě po jejím vydání jsme obdrželi výtisky, abychom mohli začít pracovat na novém vydání. (Tehdy se zasílaly jen tištěné knihy, dnes překladatelé a nakladatelé dostávají celé knihy v PDF.)

Dalším krokem bylo rozhodnutí, zda pro naše vydání použijeme původní překlad Václava Duška nebo knihu vydáme v novém překladu. Překladatele se nám podařilo vypátrat (v roce 1999 mu bylo 73 let), a protože se nám jeho překlad nezdál špatný, dohodli jsme podmínky, za kterých jeho překlad vydáme. Jednou z podmínek bylo, že provede jazykovou revizi svého překladu podle nového vydání v nakladatelství Oxford UP - podmínkou každé smlouvy na nákup autorských práv je totiž to, že se př̌kládá z nejnovějš́ho vydání. 
Další podmínkou je, že se kniha překládá kompletní, takže Václav Dušek měl za úkol přeložit i nový doslov Todda Gitlina. Třetí podmínkou bylo, že bude spolupracovat na vytvoření rejstříku - české vydání z roku 1968 rejstř́ik nemá. Vzhledem k tomu, že překladatel svůj překlad revidoval podle nového vydání originálu a vznikl tak nový překlad, označili jsme naše vydání jako první.

Licenční smlouvy na vydání překladů jsou velmi přísné - nejen že se musí překlad vydat v úplnosti, ale bez souhlasu majitele autorských práv se ke knize nesmí nic přidávat. Proto jsme museli získat souhlas s tím, že naše vydání Sociologické imaginace budeme (v souladu se standardy, které jsme si stanovili pro ediční řadu MOST) moci doplnit o Millsovu bibliografii (a přehled hlavních knih o něm) a doslov Miloslava Petruska (doslov Lubomíra Sochora z roku 1968 jsme se rozhodli nepřevzít). Z nakladatelství Oxford UP nás upozornili, že doslov (resp. jeho hlavní teze a tvrzení) musí odsouhlasit Millsovi dědicové, o nichž nám bylo sděleno toto: „Note, we have learned in the past that they are very sensitive to criticism“. Odsouhlasení tezí doslovu probíhalo v únoru roku 2000 a dopadlo dobře. Millsova dcera Kate Mills nám byla velmi nápomocná - poslala nám kompletní seznam prací svého otce a životopisné údaje. ${ }^{1}$

Souběžně s vyjednáváním obou smluv (s Oxford UP a s překladatelem) přišel prof. Emanuel Pecka s nápadem, že bychom mohli zažádat o grant GAČR na revizi překladu a jeho úpravy. O grant jsme v roce 2000 zažádali a dostali jsme ho (ve výši 72000 Kč), což se s odstupem 20 let jeví jako dosti neuvěřitelné (že totiž někdo považoval překlad za odbornou práci hodnou takové podpory). Cílem bylo revidovat původní překlad tak, aby plně odpovídal originálu a současným požadavkům na úroveň překládání odborné společenskovědní literatury. K úpravám překladu se bohužel nedochovaly žádné podklady, nebot' složky s korekturami byly uloženy ve skladu, kde je zničila povodeň v zárí 2002. Zůstala jen moje ediční poznámka v knize, v níž konstatuji, že zpřesňování překladu se nejvíce dotklo pojmů $z$ oblasti filozofie, sociologie a metodologie vědy. Tato terminologie nebyla v době prvního vydání překladu v češtině tak rozvinutá. Posouzení toho, jaký byl výsledek našeho tehdejšího snažení, bylo a je na čtenářích. Zpětné vazby, třeba v podobě zmínky v recenzi, jsme se bohužel nedočkali.

Pro zajímavost ještě uvedu pár čísel o prodeji knihy a druhém vydání. V březnu roku 2002 knížka konečně vyšla, v nákladu 1050 výtisků. Do konce roku 2006, kdy vypršela šestiletá licence, se prodalo 724 výtisků, 126 výtisků zničila povodeň a 73 výtisků bylo poskytnuto zdarma (jako autorské výtisky, recenzní výtisky apod.). Po vypršení licence jsme se rozhodli pro druhé vydání, které vyšlo v roce 2008. Žádali jsme o licenci na delší období než jen šesti let, ale neúspěšně. Tušili jsme, že druhé vydání se už nebude prodávat tak dobře, ale chtěli jsme, aby kniha byla na českém knižním trhu dlouhodobě k dispozici, proto jsme se pro druhé vydání rozhodli. Do konce platnosti licence se z nákladu 1100 výtisků při stejné prodejní ceně prodalo jen 461 výtisků. Abychom mohli knihu nadále prodávat, zaplatili jsme pak ještě dvakrát poplatek zvaný refresh. Knížku můžeme prodávat do konce roku 2020, dál už ne. Poté již nebude na trhu, dokud někdo nekoupí licenci.

1 Kate (Kathryn) Mills tehdy spolu se svou sestrou Pamelou připravovala k vydání Letters and autobiographical writings Charlese W. Millse. Kniha vyšla v roce 2000 v University of California Press. 
Bude ale v antikvariátech, kde si ji v prvním vydání z roku 1968 opatřili mnozí kolegové a kolegyně, jak bylo vidět na kolokviu „Šedesát let Sociologické imaginace“. Zdá se, že snažení SLONa o vydání kvalitnějšího překladu bylo nakonec zbytečné. S dosahem nákladu prvního vydání ( 6500 výtisků) nemůže SLON se 2150 výtisky (z nichž cca 450 je dosud neprodaných) ani po dvaapadesáti letech soutěžit.

\section{LITERATURA}

Mills, C. W. (1968). Sociologická imaginace. Praha: Mladá fronta.

Mills, C. W. (2000). The Sociological Imagination (Fortieth Anniversary Edition). Oxford / New York: Oxford University Press.

Mills, C. W. (2002). Sociologická imaginace. Praha: Sociologické nakladatelství (SLON). 